\title{
Compositional analysis of silicon oxide/silicon nitride thin films
}

\author{
Samir Meziani ${ }^{1 *}$, Abderrahmane Moussi $^{1}$, Linda Mahiou $^{1}$, Ratiba Outemzabet $^{2}$ \\ ${ }^{1}$ CRTSE, Division Développement des Dispositifs de Conversion á Semi-conducteurs. 02 Bd Frantz Fanon, BP 140 Alger \\ 7-Merveilles 16038, Algeria \\ ${ }^{2}$ Laboratoire des semi-conducteurs et oxydes métalliques, Université des Sciences et de la Technologie Houari Boumediene, \\ BP 32 El Alia, Bab Ezzouar Alger, Algeria
}

\begin{abstract}
Hydrogen, amorphous silicon nitride $\left(\mathrm{SiN}_{\mathrm{x}}: \mathrm{H}\right.$ abbreviated $\mathrm{SiN}_{\mathrm{x}}$ ) films were grown on multicrystalline silicon (mc-Si) substrate by plasma enhanced chemical vapour deposition (PECVD) in parallel configuration using $\mathrm{NH}_{3} / \mathrm{SiH}_{4}$ gas mixtures. The $\mathrm{mc}-\mathrm{Si}$ wafers were taken from the same column of Si cast ingot. After the deposition process, the layers were oxidized (thermal oxidation) in dry oxygen ambient environment at $950{ }^{\circ} \mathrm{C}$ to get oxide/nitride (ON) structure. Secondary ion mass spectroscopy (SIMS), Rutherford backscattering spectroscopy (RBS), Auger electron spectroscopy (AES) and energy dispersive X-ray analysis (EDX) were employed for analyzing quantitatively the chemical composition and stoichiometry in the oxide-nitride stacked films. The effect of annealing temperature on the chemical composition of ON structure has been investigated. Some species, $\mathrm{O}, \mathrm{N}, \mathrm{Si}$ were redistributed in this structure during the thermal oxidation of $\mathrm{SiN}_{\mathrm{x}}$. Indeed, oxygen diffused to the nitride layer into $\mathrm{Si}_{2} \mathrm{O}_{2} \mathrm{~N}$ during dry oxidation.
\end{abstract}

Keywords: SiN ${ }_{x}: H$; oxidation; PECVD; annealing temperature; elemental analysis

(C) Wroclaw University of Technology.

\section{Introduction}

Amorphous silicon nitride films are known to be very useful for different aspects in materials science. These films are used as an excellent material for technological applications [1], including solar cells [2], radiative cooling [3], gate dielectric [4], etc. Silicon nitride $\left(\mathrm{SiN}_{\mathrm{x}}\right)$ films can be deposited by different CVD techniques. PECVD is one of the methods most often used. The use of $\mathrm{SiH}_{4}$ as a silicon source and $\mathrm{NH}_{3}$ as a nitrogen source produces commonly a substantial amount of hydrogen (>10 at.\%) in the films, forming $\mathrm{Si}-\mathrm{H}$ and $\mathrm{N}-\mathrm{H}$ bonds [5]. Amorphous films grown by PECVD at temperature in the range of $300{ }^{\circ} \mathrm{C}$ to $400{ }^{\circ} \mathrm{C}$ have almost stoichiometric composition $\left(\mathrm{Si}_{3} \mathrm{~N}_{4}\right)$. Oxidation of $\mathrm{SiN}_{\mathrm{x}}$ depends on temperature, atmosphere type and physical properties of the oxide layer [6]. As thermally grown layers, silicon oxide $\left(\mathrm{SiO}_{2}\right)$ is obtained by a long-time energy-intensive high

*E-mail: mezianisam@yahoo.fr temperature process $\left(\sim 1000{ }^{\circ} \mathrm{C}\right)$ [7]. Oxide/nitride $(\mathrm{ON})$ structure is considered as a good structure for passivation and antireflection coatings (ARC) in solar cells $[8,9]$. The oxidation product nucleates and grows laterally to produce a continuous film on the surface. The nuclei growth is due to the oxygen adsorbed on the $\mathrm{SiN}_{\mathrm{X}}$ sample surface causing simultaneously oxygen depletion in the zone around each nucleus and inhibiting the nuclei formation. The literature shows some databases about $\mathrm{SiN}_{\mathrm{x}}$ oxidation in different test conditions [10]. Du et al. [11] verified that the oxidation process of $\mathrm{SiN}_{\mathrm{x}}$ is limited by the reaction kinetics and not by the mass transport. When silicon nitride is oxidized by $\mathrm{O}_{2}$ diffusion, a damaged zone is formed at the nitride-oxide interface. This phenomena accelerates the oxidation [12], which occurs in three stages: (i) oxygen adsorption on the surface of nitride; (ii) oxygen nucleation at the interface; (iii) growth of oxide layer. The oxidation of PECVD grown $\mathrm{SiN}_{\mathrm{X}}$ obeys a parabolic law as a function of time, similar to silicon oxidation. 
The chemical composition of each layer needs to be determined precisely because the electrical properties of the dielectric films depend on the chemical composition of each layer in the $\mathrm{ON}$ structure. However, it is very difficult to determine the precise stoichiometry of each layer in the ultrathin oxide-nitride films, because of experimental uncertainties due to surface roughening, preferential sputtering effect for depth profiles, different Auger electron escape depth for each element and actual interface width [13].

The purpose of our investigations is the use of four complementary analytical ion beam techniques to study the ON structure. We report on a comparative compositional analysis of oxidenitride films obtained through thermal oxidation, by four different methods based on X-ray, electron and ion scattering. In particular, energy dispersive X-ray spectroscopy (EDX), Auger electron spectroscopy (AES), Rutherford backscattering spectroscopy (RBS) and secondary ion mass spectroscopy (SIMS) were used. These methods are different not only in their physical principle but also with respect to several practical aspects. For example, EDX and AES require calibration and, therefore, appropriate standards are necessary, whereas RBS provides quantitative composition data directly. SIMS analysis is commonly used in oxide-nitride film depth profiling [14-16] and particularly to quantify very light elements such as hydrogen. However, quantitative nitrogen distribution with subnanometer depth resolution is still an analytical challenge. The experimental details are given in Section 2. Section 3 presents the experimental results obtained from SIMS, RBS, AES and EDX measurements. Finally, major results of this work are summarized in Section 4.

\section{Experimental}

In this work we used Heat Exchange Method (HEM) multicristalline $\mathrm{Si}$ (mc-Si), $10 \mathrm{~cm} \times 10 \mathrm{~cm}$ wafers, $350 \mu \mathrm{m}$ thick, boron doped, p-type, $1 \Omega \cdot \mathrm{cm}$ resistivity. All the samples having a similar crystal structure were taken from the same column of an ingot. Front polished Cz-Si wafers, p-type,
(1 $\left.\begin{array}{lll}1 & 0\end{array}\right)$ oriented, $2 \Omega \cdot \mathrm{cm}$ resistivity were used only for investigation by ellipsometry. The wafers were cleaned by etching in dilute hydrofluoric acid for removing organic contaminations and native oxide, rinsed in deionized water and dried with nitrogen. Then, $\mathrm{SiN}_{\mathrm{x}}$ film was immediately deposited on the Si substrates in a PECVD system. The precursor gases used were of ultrahigh purity electronic grade $\mathrm{SiH}_{4}$ and $\mathrm{NH}_{3}$. Electronic grade mass flow controllers allowed independent control of all gas flow parameters. The vacuum system provided a residual pressure of about $133 \mathrm{mPa}$. The flow gas ratio $\mathrm{R}=\mathrm{NH}_{3} / \mathrm{SiH}_{4}$, the deposition pressure, deposition time, temperature and the plasma power were kept constant at $6,227 \mathrm{~Pa}, 160 \mathrm{~s}, 380{ }^{\circ} \mathrm{C}$ and $4.6 \mathrm{~kW}$, respectively.

In this experiment, $\mathrm{SiN}_{\mathrm{x}}$ films were oxidized in dry oxygen at $950{ }^{\circ} \mathrm{C}$ in a controlled $\mathrm{O}_{2}$ atmosphere to obtain the final ON structure. Refractive indices and thicknesses were measured by a single wavelength $(632.8 \mathrm{~nm})$ ELX-02 C DRE ellipsometer employing $\mathrm{He}-\mathrm{Ne}$ laser beam at an angle of $70^{\circ}$.

For SIMS depth profiling, IMS4FE7-CAMECA instrument was used. The primary bombarding beam source was $\mathrm{Cs}^{+}$, and secondary ions were monitored for each species of interest (in this case, $\mathrm{N}, \mathrm{O}, \mathrm{H}$ and $\mathrm{Si}$ ). Primary beam impact energy of $15 \mathrm{keV}$, incidence angle of $24^{\circ}$, and depth resolution less than $2 \mathrm{~nm}$ were the conditions used in this analysis. Nitrogen and oxygen and hydrogen profiles were quantified using suitable standards. The relative sensitivity factor (RSF) obtained in the analytical conditions was $2.37 \times 10^{16} \mathrm{at} / \mathrm{cm}^{3}$. The sputtering rates for each element were about: $8.779 \AA / \mathrm{s}$, $9.279 \AA / \mathrm{s}$ and $9.103 \AA / \mathrm{s}$ for nitrogen, oxygen and hydrogen, respectively.

Rutherford backscattering (RBS) was used to determine the $\mathrm{Si}, \mathrm{N}$ and $\mathrm{O}$ atomic concentrations, as well as the density of the nitride and oxide in the samples. The Van der Graaf tendem accelerator was located in the Centre de Recherche Nucléaire d'Alger (CRNA) and equipped with a $2 \mathrm{MeV} \mathrm{He}^{2+}$ ion beam. Incident beam hit the sample at incidence angles of $70^{\circ}$ and $0^{\circ}$ (as referred to the normal of the surface), the detection angle of $170^{\circ}$ and the current of $50 \mathrm{nA}$ were used. After 
the background correction, the experimental spectra were simulated using the SIMNRA program [17] to determine the stoichiometry and the areal density. The parameters set included the elements concentrations (except that of hydrogen).

AES measurement was performed with a cylindrical mirror analyzer with an energy resolution $\Delta \mathrm{E} / \mathrm{E}=0.6 \%$. The energy of primary electron was $5 \mathrm{keV}$. The Auger spectra were recorded in the derivative mode. In order to check the homogeneity of the film composition, depth profiling was carried out by alternating measurements of Auger spectra and sputtering the sample surface with $4 \mathrm{keV}$ $\mathrm{Ar}^{+}$ions.

Energy dispersive X-ray (EDX) spectra were recorded with a scanning electron microscope (Philips ESEM-XL30-FEG) equipped with a fieldemission cold cathode as an electron source and a $\mathrm{Si}$ (Li) X-ray detector. Typically, the electron accelerating voltage was $5 \mathrm{keV}$ and the detection takeoff angle $35^{\circ}$. The correction was applied to determine the relative atomic fractions of the three components N, O and Si. Hydrogen could not be detected by this method.

\section{Results and discussion}

SIMS was used to confirm the presence of desired elements and the absence of undesired elements such as carbon impurities, and also to demonstrate that the elemental content was homogeneous throughout the ON structure. Fig. 1 shows the SIMS results for an ON sample annealed at $700{ }^{\circ} \mathrm{C}$ for $30 \mathrm{~min}$ in nitrogen ambient atmosphere. Silicon, oxygen, nitrogen and hydrogen signals, also reported, prove the presence of these elements in the ON structure. Thanks to SIMS analysis we could identify the different layers existing in the ON structure. We found the thickness of $0.037 \mu \mathrm{m}, 0.069 \mu \mathrm{m}$ and $0.006 \mu \mathrm{m}$ for $\mathrm{SiO}_{2}, \mathrm{SiN}_{\mathrm{x}}$ and $\mathrm{Si}_{2} \mathrm{O}_{2} \mathrm{~N}$, respectively.

Ellipsometric measurements of thickness (e) and refractive index (n) of as deposited layers gave $\mathrm{e}=80 \mathrm{~nm}, \mathrm{n}=2$ for silicon nitride and $\mathrm{e}=40 \mathrm{~nm}$, $\mathrm{n}=1.47$ for silicon oxide. The thickness of $\mathrm{SiN}_{\mathrm{x}}$

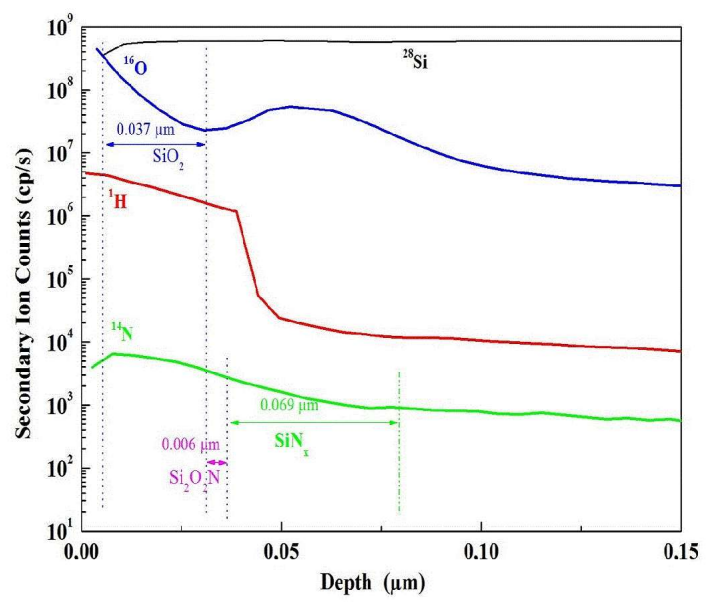

Fig. 1. Depth profiles of $\mathrm{Si}, \mathrm{O}, \mathrm{N}$ and $\mathrm{H}$ in an $\mathrm{ON}$ structure annealed at $700{ }^{\circ} \mathrm{C}$.

layer has been reduced from $80 \mathrm{~nm}$ to $69 \mathrm{~nm}$ after oxidation and heat treatment at $700{ }^{\circ} \mathrm{C}$.

Fig. 2 depicts the SIMS oxygen depth profiles for several samples as-deposited and annealed at different temperatures. As shown in the figure, remarkable oxygen tails are found as secondary ion as a result of $15 \mathrm{keV} \mathrm{Cs}^{+}$ion sputtering. From the SIMS measurements, we have found high-oxygen content on the surface. Indeed, this was due to the oxidation growth effect on nitride [18]. We observed a pile-up of oxygen at the $\mathrm{SiO}_{2} / \mathrm{SiN}_{\mathrm{x}}$ interface at the depth around $0.05 \mu \mathrm{m}$ that forms the oxynitride phase.

The $\mathrm{Si}_{2} \mathrm{O}_{2} \mathrm{~N}$ species come from broken bonds that exist as an intermediate phase between the $\mathrm{SiO}_{2}$ and the $\mathrm{SiN}_{\mathrm{x}}$. However, a form of a complete distribution could be derived directly from the distribution of respective quasi-molecular ions. So, we think that $\mathrm{Si}_{2} \mathrm{O}_{2} \mathrm{~N}$ can exist in the silicon oxidesilicon nitride interfaces. The $\mathrm{SiN}_{\mathrm{x}}$ and the $\mathrm{SiO}_{2}$ phases never coexist in the bulk under equilibrium conditions. They are always separated by silicon oxynitride, $\mathrm{Si}_{2} \mathrm{O}_{2} \mathrm{~N}$ [13].

Fig. 3 presents a joint plot of $\mathrm{Si} / \mathrm{N}$ versus depth at different annealing temperatures as calculated from the data obtained by SIMS. The data points refer to the $\mathrm{ON}$ sample oxidized at $950{ }^{\circ} \mathrm{C}$ by dry oxidation. As shown in Fig. 3, again an excess of silicon component is observed. This can 


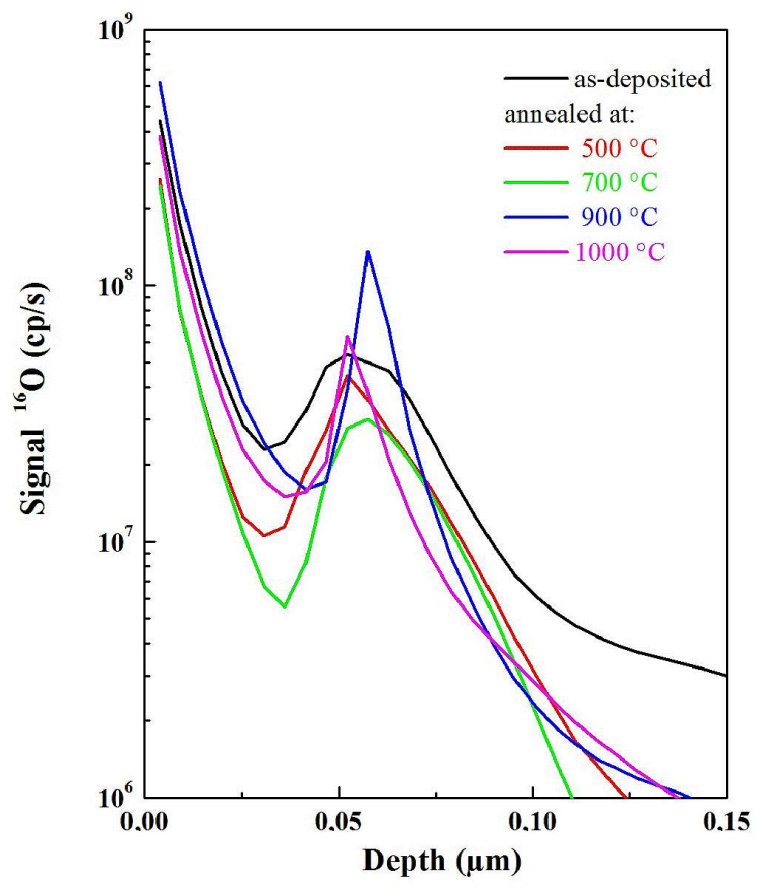

Fig. 2. SIMS depth distribution of oxygen concentration for samples annealed at different temperatures.

be explained by the fact that the signal of $\mathrm{Si}$ is higher than that of $\mathrm{N}$ in every annealing temperature. In the range of depth between 0 and $0.50 \mu \mathrm{m}$, we can see that $\mathrm{Si} / \mathrm{N}$ ratio increases when the annealing temperature increases from as-deposited to $700{ }^{\circ} \mathrm{C}$.

However, beyond $700{ }^{\circ} \mathrm{C}$, the $\mathrm{Si} / \mathrm{N}$ ratio decreases. This is probably due to low amount of $\mathrm{Si}$ atoms and the recoiled nitrogen atoms during $\mathrm{Cs}^{+}$ ion sputtering that are affected by the high annealing temperature.

SIMS analysis of the oxide/nitride films suggests that the resulting profile of oxygen/nitrogen concentration ratio (Fig. 4) yields one large peak near the dielectric surface of $\operatorname{SiN}_{x}$. This is due to the presence of silicon oxynitride thin film in this region. When the annealing temperature increases, the $\mathrm{O} / \mathrm{N}$ ratio increases with annealing temperature up to $900{ }^{\circ} \mathrm{C}$. Indeed, when the temperature of annealing step increases, the oxidized dielectric film becomes larger. So, more oxygen is incorporated into the dielectric film, and therefore, the oxygen

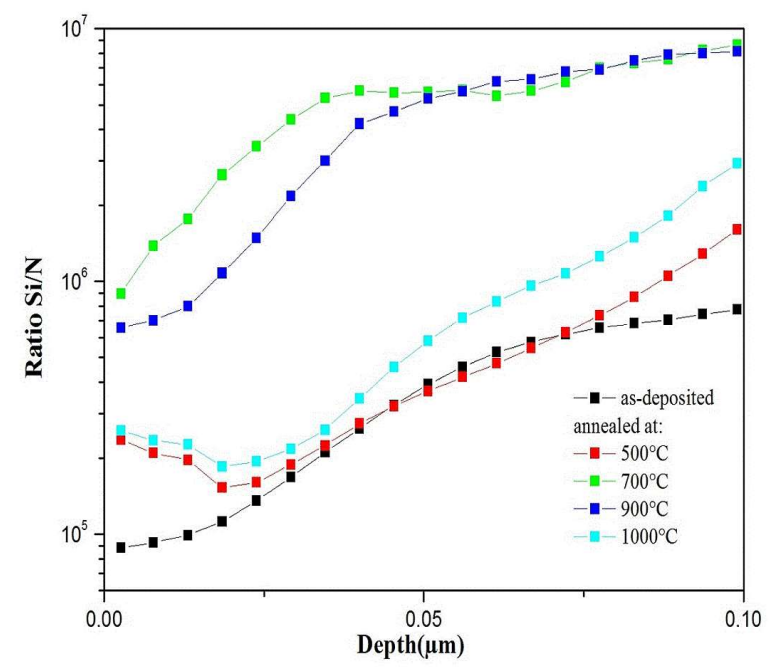

Fig. 3. SIMS depth distributions of $\mathrm{Si} / \mathrm{N}$ ratio on ON structure for as-deposited and annealed at: $500{ }^{\circ} \mathrm{C}, 700{ }^{\circ} \mathrm{C}, 900{ }^{\circ} \mathrm{C}$ and $1000{ }^{\circ} \mathrm{C}$.

atoms substitute the nitrogen atoms which induces the formation of thin silicon oxynitride layer [19].

The chemical composition of each layer needs to be determined precisely because the electrical properties of the dielectric films depend on the chemical composition of each layer in the ON structure. Hong et al. [20] determined that there is a direct correlation between the mass density of $\mathrm{SiN}_{\mathrm{x}}$ films and the concentration of $\mathrm{Si}-\mathrm{N}$ bonds, as determined by FT-IR. In the meantime, Weeber et al. [21] have shown that the maximum $\mathrm{Si}-\mathrm{N}$ bond concentration corresponds to stoichiometric $\mathrm{SiN}_{\mathrm{x}}\left(\mathrm{Si}_{3} \mathrm{~N}_{4}\right)$ with the refractive index in the vicinity of $n=2$. Some authors reported that high surface passivation quality could be maintained for $\mathrm{ARC} \mathrm{SiN}_{x}$ or double antireflection coating (DARC) $\mathrm{SiO}_{2} / \mathrm{SiN}_{\mathrm{x}}$ after annealing in forming gas atmosphere. Fourier transformed infrared absorption measurements revealed a strong dependence of the annealing temperature on the stability of $\mathrm{Si}-\mathrm{N}$ bonding density. The passivation quality after the firing process depended strongly on the $\mathrm{Si}-\mathrm{H}$ bonding density. Jehanathan et al. [22], and Lelièvre et al. [23] stated that the annealing leads first to breaking $\mathrm{Si}-\mathrm{H}$ bonds which are less thermally stable than $\mathrm{N}-\mathrm{H}$ (bond energy $\mathrm{Si}-\mathrm{H}$ and $\mathrm{N}-\mathrm{H}$ are $3.1 \mathrm{eV}$ and $4.1 \mathrm{eV}$, respectively). 
The general trend is that the hydrogen content in the stacks decreases with increasing annealing temperature.

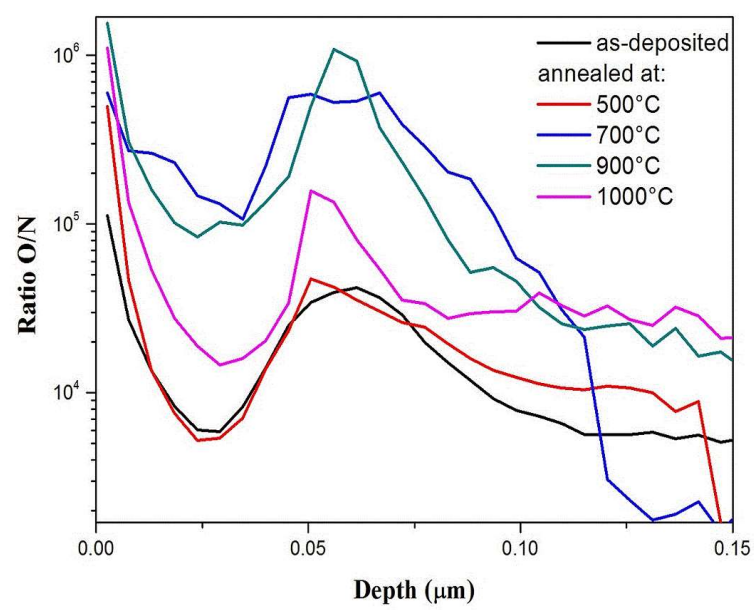

Fig. 4. SIMS depth distributions of $\mathrm{O} / \mathrm{N}$ ratio for as deposited and annealed films at temperatures $500{ }^{\circ} \mathrm{C}, 700{ }^{\circ} \mathrm{C}, 900{ }^{\circ} \mathrm{C}$ and $1000{ }^{\circ} \mathrm{C}$.

Additionally, the global composition of the films in ON structure was determined by Rutherford backscattering spectrometry (RBS) using a $2 \mathrm{MeV} \mathrm{He}^{2+}$ beam. The spectra were analyzed using SIMNRA simulation program [17]. Experimental data as well as simulation results are shown in Fig. 5 for a $\mathrm{SiO}_{2} / \mathrm{SiN}_{\mathrm{x}}$ sample. The simulation reproduces correctly the experimental signal of the sample. We have found by the RBS analysis that the silicon nitride layer deposited by PECVD with $\mathrm{R}\left(\mathrm{NH}_{3} / \mathrm{SiH}_{4}\right)=6$ is stoichiometric $\mathrm{Si}_{3} \mathrm{~N}_{4}$. On the other hand, thermal oxidation also gives stoichiometric silicon oxide $\mathrm{SiO}_{2}$.

The concentration profile for $\mathrm{Si}, \mathrm{N}$ and $\mathrm{O}$ atoms derived from the background-subtracted data and the obtained results (figure not shown) as a function of annealing temperature show that silicon and oxygen concentrations increase with annealing temperature. However, nitrogen concentration decreases as annealing temperature increases. This behavior can be correlated with the results obtained by SIMS.

We have used AES in order to check the homogeneity of the ON structure [24]. AES spectra have been collected for the sample annealed at $700{ }^{\circ} \mathrm{C}$

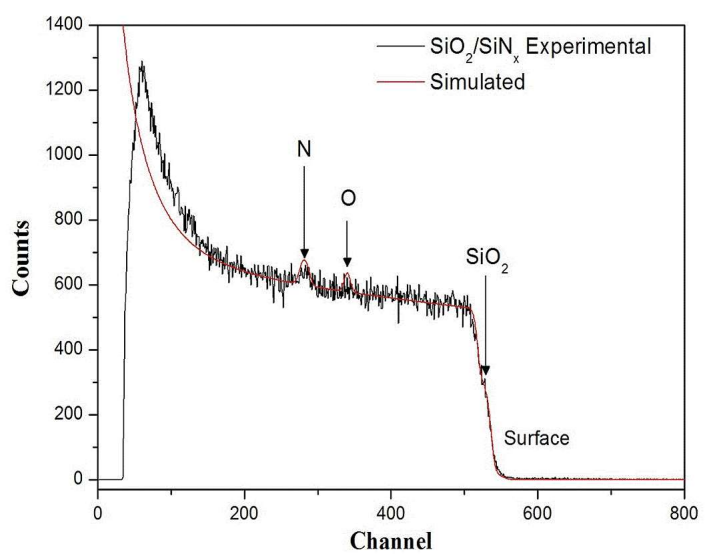

Fig. 5. Typical RBS spectrum of ON structure recorded with $\mathrm{He}^{+2}$ ions at $2 \mathrm{MeV}$. Simulation by SIMNRA is given for comparison. Chemical symbol arrows are given to show the signal of each element located at the film surface.

during 30 min in $\mathrm{N}_{2}$ atmosphere (Fig. 6). The spectra have been normalized and show that the sample contains oxygen and nitrogen in the amounts in agreement with SIMS and RBS data. This spectrum is related to the interface region. In this region, $\mathrm{O}$ comes from a superficial oxidation of silicon nitride and this region reveals a presence of low intensity N KLL peak.

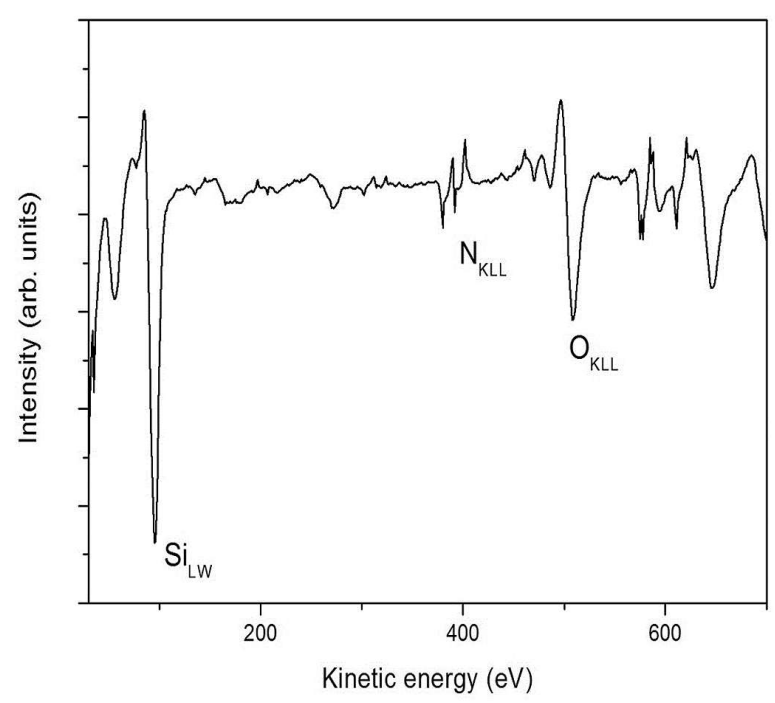

Fig. 6. First derivative AES survey spectrum of oxide/nitride film obtained after dry oxidation of $\mathrm{SiN}_{\mathrm{x}}$ and annealed at $700{ }^{\circ} \mathrm{C}$ during $30 \mathrm{~min}$. 
The $\mathrm{SiN}_{\mathrm{x}}$ oxidation as a function of annealing temperature has been explained by assuming that the oxidant species diffuses towards the $\mathrm{SiN}_{\mathrm{X}}$ /oxide interface where it reacts with the silicon nitride. In addition, it is considered that under steady state conditions the flux of oxygen is constant at any point in ON system. Something that remains as unknown is the actual chemical reaction occurring during oxidation.

A typical EDX spectrum of oxide/nitride film is shown in Fig. 7. Typically, the electron accelerating voltage was $5 \mathrm{keV}$ and the detection take-off angle was $35^{\circ}$. Fig. 8 presents a joint plot of $\mathrm{X}=\mathrm{N} / \mathrm{Si}$ and $\mathrm{X}^{\prime}=\mathrm{O} / \mathrm{Si}$ calculated from the data obtained by EDX versus annealing temperature. The data points refer to the sample of $\mathrm{SiN}_{\mathrm{X}}$ series deposited with $\mathrm{R}=6$ and oxidized at $950{ }^{\circ} \mathrm{C}$ during 3 hours.

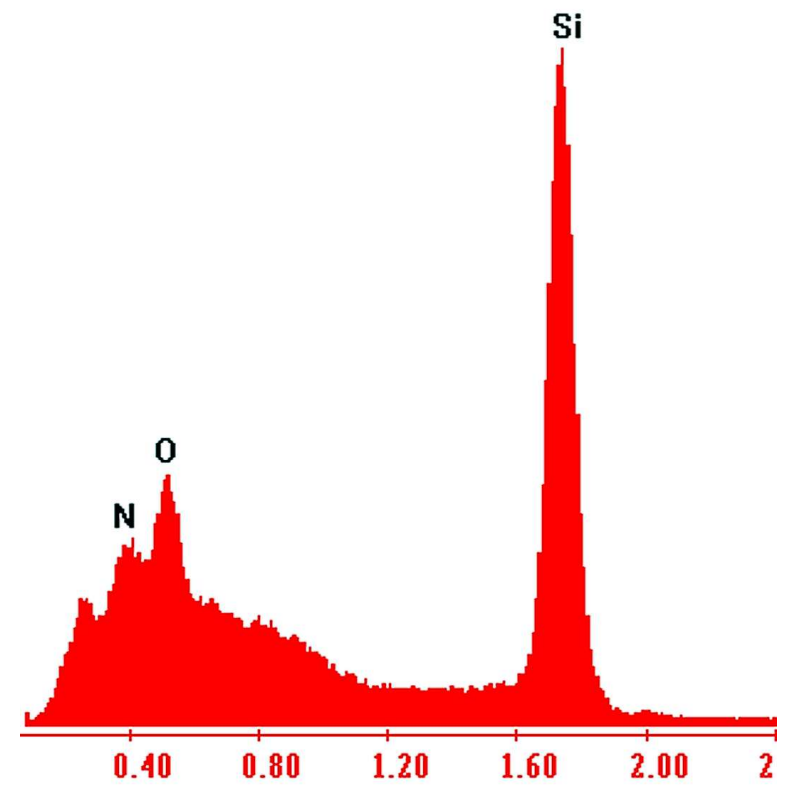

Fig. 7. The EDX spectrum of a typical oxide/nitride film with similar amounts of nitrogen and oxygen. Electron beam energy: $5 \mathrm{keV}$ and the detection take-off angle $35^{\circ}$.

Although EDX does not deliver information on hydrogen, the other components $(\mathrm{Si}, \mathrm{N}$, and $\mathrm{O}$ ) can be readily analyzed with sufficient accuracy if well certified reference samples are also available for the intermediate composition ranges.

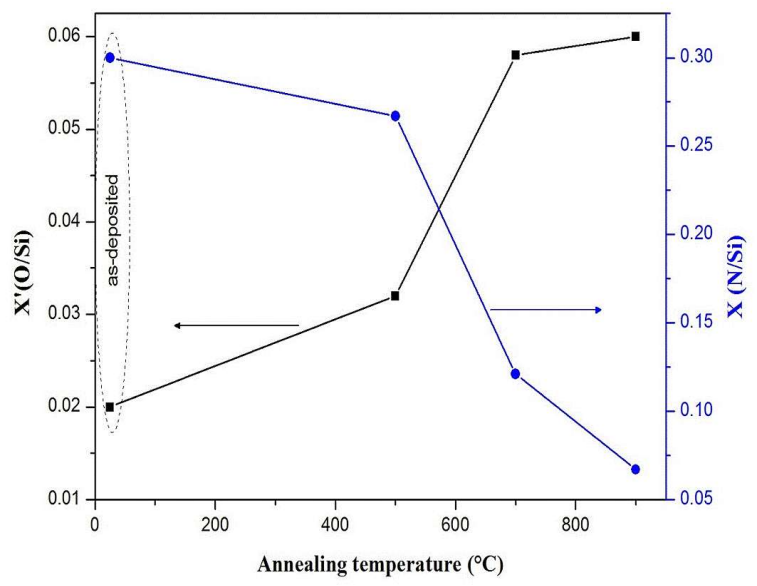

Fig. 8. Correlation between $\mathrm{O} / \mathrm{Si}$ and N/Si with annealing temperature determined by $\mathrm{EDX}$ in oxide/nitride film oxidized at $950{ }^{\circ} \mathrm{C}$ during 3 hours. The $\operatorname{SiN}_{\mathrm{x}}$ films were deposited by PECVD with $\mathrm{R}=6$.

It should be noted that there is a similar tendency in the variation of $\mathrm{O} / \mathrm{Si}$ and $\mathrm{N} / \mathrm{Si}$ between EDX and RBS measurements. In both analyses, we have found that the $\mathrm{O} / \mathrm{Si}$ increases with annealing temperature, whereas N/Si decreases. The RBS measurement confirms that the $\mathrm{O} / \mathrm{Si}$ and N/Si determined by EDX are credible. The higher the annealing temperature the higher the incorporated amount of oxygen in the structure.

\section{Conclusion}

In this work, we determined the composition of silicon nitride $\left(\mathrm{SiN}_{\mathrm{x}}\right)$ films oxidized in dry oxygen at $950{ }^{\circ} \mathrm{C}$. Silicon nitride was obtained by PECVD from a mixture of gases $\mathrm{SiH}_{4}$ and $\mathrm{NH}_{3}$. The annealing temperature used in the treatment of the oxide/nitride film had a strong influence on the composition of the ON structure. Reasons of this variation should be found in the atomic composition that has been determined by SIMS, RBS, AES and EDX. The $\mathrm{SiN}_{\mathrm{x}}$ layers prepared with $\mathrm{R}=6$ have a stoichiometric $\mathrm{Si}_{3} \mathrm{~N}_{4}$ structure. Likewise, the oxidation of $\mathrm{SiN}_{x}$ leads to growing of silicon oxide with stoichiometric $\mathrm{SiO}_{2}$ structure. It should 
be mentioned that the ratio of N/Si decreases with annealing temperature while the $\mathrm{O} / \mathrm{Si}$ ratio increases. So, more oxygen is incorporated into the dielectric film, and therefore, the oxygen atoms substitute the nitrogen atom which induces the formation of thin silicon oxynitride layer.

\section{Acknowledgements}

The work was funded by the National Research Fund DGRSDT MESRS/Algeria and has been supported by the Centre de Recherche en Technologie des Semi-conducteurs pour l'Energétique (CRTSE).

\section{References}

[1] Sze S.M., J. Appl. Phys., 38 (1967), 2951.

[2] El Amrani A., Bekhtari A., Mahmoudi B., LeFgoum A., Menari H., Vacuum, 86 (2011), 386.

[3] Parm I.O., Kim K., Lim D.G., LeE J.H., HeO J.H., KIM J., KIM D.S., LEE S.H., Yi J., Sol. Energ. Mat. Sol. C, 74 (2002), 97.

[4] Liang Z., Shen H., Li J., Xu N., Sol. Energy, 72 (2002), 505.

[5] Ay F., Aydinli A., Opt. Mater., 26 (2004), 33.

[6] Taguchi S.P., Ribeiro S., J. Mater. Process Tech., 147 (2004), 336.

[7] Aberle A.G., Prog. Photovolt. Res. Appl., 8(2000), 473.

[8] Panek P., Drabczyk K., Focsa A., Slaoui A., Mater. Sci. Eng. B-Adv., 165 (2009), 64.

[9] Hofmann M., Schneiderlochner E., Wolke W., PREU R., Silicon Nitride-Silicon Oxide Stacks for Solar Cell Rear Side Passivation, $19^{\text {th }}$ European Photovoltaic Solar Energy Conference, 7 - 11 June 2004, Paris.

[10] PAN X., J. Am. Ceram. Soc., 79 (1996), 2975.

[11] Du H., Tressler R.E., SPEAR K.E., J. Electrochem. Soc., 136 (1989), 3210.

[12] Banerji N., Serra J., Gonzalez P., Chiussi S., Parada E., LeON B., Perez-Amor M., Thin Solid Films, 317 (1998), 214.
[13] LeE S., Kim B., Kim J-Y., An H-M., Seo K-Y., Thin Solid Films, 515 (2007), 6915.

[14] Bersani M., Vanzetti L., Sbetti M., AnDERLE M., Appl. Surf. Sci., 144 - 145 (1999), 301.

[15] Frost M.R., Magee C.W., Appl. Surf. Sci., 104 - 105 (1996), 379.

[16] Bouvet D., Clivaz P.A., Dutoit M., Coluzza C., Almeida J., Margaritondo G., Pio F., J. Appl. Phys., 79 (1996), 7114.

[17] MAYER M., SIMNRA User's Guide. Report IPP, Vol. 9/113, Max-Planck-Institut fur Plasmaphysik, Garching, 1997.

[18] Poon M.C., GaO Y., KoK T.C.W., Myasnikov A.M., Wong H., Microelectron. Reliab., 41 (2001), 2071.

[19] Kimura K., Nakajima K., Kobayashi H., Miwa S., S ATORI K., Appl. Surf. Sci., 203 - 204 (2003), 418.

[20] Hong J., Kessels W.M.M., Soppe W., Rieffe H.C., WeEber A.W., SANDEN VAN DE M.C.M., $3^{r d}$ World Conference on Photovoltaic Energy Conversion, Osaka, Japan, Arisumi Printing Inc., Osaka, 2003, p. 1158.

[21] Weeber A.W., RiefFe H.C., Sinke W.C., Soppe W.J., Proceedings of the $19^{\text {th }}$ European Photovoltaic Solar Energy Conference, Paris, 2004, p. 1005.

[22] Jehanathan N., Saunders M., LiU Y., Dell J., Scripta Mater, 57 (2007), 739.

[23] Lelièvre J.F., Fourmand E., Kaminski A., Palais O., Ballutaud D., Lemiti M., Sol. Energ. Mat. Sol. C., 93 (2009), 1281.

[24] Vila M., Martin-Gago J.A., Munoz-Martin A., Prieto C., Miranzo P., Osendi M.I., GarciaLOPEZ J., REsPALDIZA M.A., Vacuum, 67 (2002), 513.

Received 2015-06-23

Accepted 2016-04-28 